\title{
Jornalismo e configuração narrativa da história do presente
}

\author{
Luiz Gonzaga Motta*
}

\begin{abstract}
Resumo
O artigo indaga inicialmente como construimos sentidos a partir dos fragmentos de significação das noticias diárias. Pergunta até onde a linguagem objetiva e descritiva do jornalismo pode ser compreendida como expressão narrativa. Para responder, procura identificar a essência do paradigma narrativo. Conclui que a narratividade dos enunciados jornalisticos não deve ser procurada no estilo, na referencialidade, na ordenação cronológica dos fatos nem na composição da intriga. A narratividade do jornalismo, propõe o argumento, está na sua compreensão como processo de conhecimento, na sua ação cognitiva. A narratividade deve ser procurada no círculo mimético, especialmente no ato de recepção e interpretação onde a realidade temporal se recompõe na experiência cultural dos atos de leitura. È o leitor que conclui narrativamente as fragmentadas noticias do dia a dia preenchendo as lacunas, tecendo os fios dos acontecimentos jornalisticos em histórias mais ou menos integrais e realizando continuamente, através de provisórias narrativas jornalisticas, a experimentação de valores éticos e morais.
\end{abstract}

Palavras-chave: paradigma narrativo, narratividade, teoria da recepção, narrativa jornalistica, acontecimento midiático, história do presente.

\begin{abstract}
How do we compose meanings from the fragmented daily news story? Can the objective and descriptive journalistic language be understood as narrative? The article initially attempts to answer these questions through the identification of the essence of the narrative paradigm. It concludes, however, that the narrative nature of journalistic language should not be searched in news style neither in its referential orientation or the chronological orientation of facts that may compose a integral history. The narrative nature of journalism, follow the argument, is in its comprehension as a knowledge process or cognitive action. The narrative nature of journalism should be finding in the mimetic circle, especially at the reception practices and the interpretation courses, when the temporal reality is recomposed throughout the cultural experience of reading and viewing. It is the reader or viewer who narrativelly concludes the fragmented daily news stories completing the discontinuities and lacunas, interweaving the course of journalistic events in more or less integrated histories. In this process the reader contimuously realizes an experimentation of ethical, moral and aesthetical values.
\end{abstract}

Keywords: narrative paradigm, narrativity: reception theory, journalistic narrative, histony of present time

\footnotetext{
* Jornalista, doutor pela University of Wisconsin, com pós doutrado na Universidade Aurônoma de Barcelona e professor da Universidade de Brasilia
} 


\author{
Ver o céu num grão \\ de areia não é \\ um ardil privativo \\ dos poetas
}

Clifford Geertz

\title{
Introdução
}

Como as desconexas significações parciais das notícias diárias são interpretadas pelos receptores? De que maneira os receptores constroem sínteses significativas a partir dos dispersos fragmentos de sentido transmitidos pelas notícias? De que maneira os receptores conformam significações coerentes a partir das fragmentadas notícias? É possível que as dispersas notícias de cada dia sejam reordenadas pela audiência em narrativas unitárias? Se isso se realiza, até onde essas reconstruções discursivas podem ser reconhecidas como narrativas coesas?

Essas perguntas nos remetem a outras perguntas prévias: existe expressão narrativa nos fragmentados relatos jornalísticos? Pode a linguagem objetiva e descritiva do jornalismo ser interpretada como narrativa? Nesse caso, há alguma semelhança entre a narrativa jornalística e a narrativa de ficção literária? Ou a narrativa jornalística está mais próxima da narrativa fática da história? Se o jornalismo produz narrativas, qual é a sua natureza? Onde e como elas se nos revelam?

A relevância dessas perguntas não se restringe a uma distinção formal do estilo jornalístico. Se concluirmos que o jornalismo é narrativa, como ele configura e nos conta as suas histórias? Como estimula e projeta a imaginação dos leitores e ouvintes? Como constrói significações?

Estamos nos referindo aqui ao jornalismo objetivo do lide e da "pirâmide invertida", das hard news ou notícias escritas na forma direta, descritiva, factual. O desafio é maior. Esse tipo de notícias constitui a essência do jornalismo diário, contrapõe-se à ficção e nega qualquer parentesco com a literatura e as artes. Queremos indagar a esse jornalismo objetivo se ele pode ser interpretado como narrativa. ${ }^{4}$

Este artigo aventura-se a inquirir se o jornalismo é uma expressão narrativa e a refletir sobre os processos de interpretação, por parte dos receptores, das fragmentadas notícias diárias. As respostas não são fáceis. Não cobriremos todo o leque conceitual aberto nem chegaremos a respostas definitivas. As inúmeras indagações estéticas, lingüisticas, cognitivas e filosóficas que estão por trás dessas perguntas ocupa ampla extensão nas reflexões recentes da filosofia e das ciências da linguagem. ${ }^{5}$

Este artigo não tem a pretensão de esgotar a discussão sobre o paradigma narrativo. Pretende, inicialmente, observar a identidade dos 
enunciados narrativos; penetrar, em seguida, na essência do paradigma narrativo; identificar onde e como o jornalismo configura-se como narrativa; discutir, nas conclusões, as implicações de considerar o jornalismo como expressão narrativa. A hipótese que nos guia é um paradoxo: o jornalismo não é ficção, mas é narrativa; como narrativa, pode ser interpretado como ficção.

\section{O enunciado objetivo do jornalismo caracteriza uma narrativa?}

Para responder tal pergunta temos de entender inicialmente o que é e o que não é narrativa como forma de expressão humana. Considerar primeiro as distinções de estilo. as qualidades inerentes do texto narrativo. Como a teoria literária distingue o texto narrativo? Tropeçamos aqui com o nosso primeiro obstáculo. Essa simples questão nos remete a inúmeras encruzilhadas e abre um amplo campo de reflexão que inclui a teoria literária, as ciências da linguagem e as teorias cognitivas cujas fronteiras e hierarquias não estão delimitadas com nitidez.

Em sua teoria da narrativa, Mieke Bal (2001, 12-17) diz que um texto narrativo é aquele em que um agente relata uma narração. Um texto narrativo, diz ele, é uma história que se conta através da linguagem. isto é, uma história que se converte em signos linguísticos. Isto implica dizer que o texto narrativo é aquele no qual se relata uma história, mas o texto não é a história. Os textos podem diferir entre si e contar a mesma história. A essência da identidade se transfere para o plano da história. que segundo Bal é uma fábula apresentada de certa maneira. Uma fábula seria uma série de acontecimentos lógica e cronologicamente relacionados que alguns atores causam ou experimentam. A definição de Bal de um texto narrativo é então formulada: é aquele onde se podem encontrar os três estratos: texıo, história, fábula. A distinção da narrativa em três estratos separados e interdependentes, como faz Bal, permiteIhe aprofundar os estudos sobre os textos narrativos, mas não resolve a questão da identidade de uma narrativa. $O$ autor acaba deixando ao analista realizar a eleição, intuitivamente. ${ }^{6}$ Se tomarmos a afirmativa de que um texto narrativo é uma narração, nos voltamos para a pergunta: o que é, então, narração? Também aqui, os esclarecimentos da teoria literária não ajudam muito. No seu Dicionário de Teoria da Narrativa, Reis e Lopes (1988) chamam a atenção sobre a polissemia do termo, observando que ele corresponde à ancestral concepção da narratio, parte da dispositio da retórica clássica que se refere à organização do discurso. A diversidade de acepções que envolvem o termo narração não impediu, entretanto, uma consolidação do termo, afirmam eles.

A primeira distinção contrapõe narração e descrição. Narração é o procedimento representativo dominado pelo relato de eventos que configuram o desenvolvimento de uma ação temporal (cronológica) que estimula a imaginação (a diegese da história). A descrição, por outro lado, é o 
procedimento representativo de um momento único, estático, temporalmente suspenso, que procura "naturalizar" o discurso e criar o efeito de real pelo excesso de informações geradoras de verossimilhança. A díade narração/ descrição não é perfeitamente simétrica. Ocorrem sempre incrustações de uma na outra. No jornalismo (como em outros gêneros) é praticamente impossível encontrar textos puramente descritivos tanto quanto aqueles exclusivamente narrativos. Entretanto, o discurso jornalístico parece tender para a descrição mais do que para a narração na medida em que sua forma direta, clara, precisa e concisa cria o efeito de real mais do que estimula imaginários.

Há uma outra oposição no campo da identidade dos enunciados que tem a ver com a questão anterior, mas é diferente. Trata-se da oposição entre aquilo a teoria literária identifica como showing $x$ telling, utilizando terminologia inglesa. O showing é a técnica de representação dramática que mostra uma sucessão de cenas e revelam situações particulares, deixando para o expectador configurar o enredo e a diegese da história (mostra, mais que narra, como no teatro e no cinema). $O$ telling se distingue pelo esforço do narrador em conectar, juntar as partes, contar enfim. Essa oposição nos remete à questão da distância (ou do posicionamento) que o narrador quer manter das coisas narradas. No showing o narrador aumenta a distância ao desvanecer a sua presença, dramatiza as histórias, privilegia as citações permitindo que as personagens e os fatos falem por si mesmos. No telling o narrador encurta a distância na medida em que se transforma no foco da narrativa, com intervenções afetivas, éticas e estéticas frequientes. ${ }^{7}$ Em relação a essa última oposição, o jornalismo tende para o showing (ainda que as duas formas possam ocorrer alternadamente num mesmo discurso jornalístico), não só porque dramatiza os fatos, atribui importância aos personagens e suas falas, mas principalmente porque o narrador procura se distanciar e deixar as conclusões éticas, morais e políticas para os leitores e ouvintes. Salvo exceções, o jornalista não pretende contar histórias (sejam elas realistas ou ficcionais), quer apenas descrever fatos tal como ocorridos na realidade. Neste sentido, afasta-se da narrativa tradicional. A confirmação da precisão dos fatos relatados ou a eventual interpretação criativa são deixadas por conta do leitor ou ouvinte, pois essas intencionalidades estão ausentes do exercício da profissão devido à precisão e imediatismo da prática jornalística.

A partir da distinção sobre o que é ou não é uma expressão narrativa conforme as oposições acima, conclui-se que os enunciados jornalísticos tendem a se afastar da forma narrativa e a se caracterizar como expressões mais descritivas e objetivas da realidade que deixam para o receptor o encargo de reconstituir representações, principalmente de fazer as conexões e de construir eventuais diegeses narrativas dos acontecimentos descritos. Diferentemente da forma narrativa, o jornalista pröcura desvanecer a sua 
presença e transforma-se num mediador discreto. Enquanto mimese. o jornalismo se restringiria a descrever objetivamente a realidade, evitando contar histórias no sentido tradicional da palavra.

Mas, o que é contar? Para Mirian Alvarez (2000. 19) contar ou narrar é relatar fatos que se produziram ao largo do tempo. A narração fixa ações relacionadas a personagens em um suceder temporal encaminhado a um determinado desenlace. Aquele que narra, segue o argumento, evoca acontecimentos conhecidos que presenciou pessoalmente ou não, e configura o relato de forma verossímil de maneira a induzir o leitor a participar como espectador quase presente nos eventos que relata. Se a singularidade do contar é fixar as ações em uma sucessão temporal, precisamos observar mais de perto essa particularidade narrativa antes de observarmos a questão do envolvimento do leitor.

Na teoria literária essa qualidade intrínseca da narrativa recebe o nome de narratividade, um conceito que está aquém do narrar. O que é, precisamente, a narratividade? Reis e Lopes (1988.69/70) fazem uma discussão do termo começando pelos teóricos do Grupo de Entrevernes (1979), para quem narratividade é uma sucessão de estados e de transformações inscritos no discurso, responsável pela produção de sentido. Reis e Lopes mostram que G. Greimas completou essa definição quando observou que a narratividade é a irrupção do descontínuo na permanência discursiva de uma vida, de uma história, de um indivíduo, de uma cultura. Ambas as definições privilegiam as transformaçōes. O destaque está no processo de transformação do contínuo ao descontínuo como manifestação da narratividade. Reis e Lopes concluem sua discussão do conceito afirmando que a narratividade constitui uma qualidade reencontrada nos textos narrativos de todas as épocas, não apenas em textos literários, mas também nas narrativas não literárias e até não verbais. A narratividade, segundo eles, remonta à estrutura profunda do tex to e envolve circunstâncias sociopsicológicas e pragmáticas da produção do texto. *

Uma primeira bifurcação se apresenta, entretanto. Outros autores retiram a propriedade da narratividade do discurso em si mesmo (qualidade intrínseca) e a transferem para a instância do receptor. Para G. Prince (1987, 64), por exemplo, o grau de narratividade de certa narrativa depende parcialmente da extensão em que a narrativa preenche o desejo dö receptor representando papéis temporalmentẹ orientados (prospectivamente. do começo para of final e retrospectivamente, do final para o começo). Embora transfira a questão para o campo virtual do receptor. esse conceito não elimina a força do princípio da transformação na conceituação do narrativo (discutiremos adiante a perspectiva do receptor).

M. Bal $(2001,57 / 59)$ trata a questão da continuidade/descontinuidade desde o seu processo inverso. Isto é, entende a narratividade desde o movimento de ordenação que se costura no texto através das relações que se estabelecem entre os personagens da história sob a base das leis que regem 
a realidade humana. Essas relações podem seguir uma ordem cronológica (umas ações depois de outras) ou lógica (ninguém sai de um lugar antes de ali haver entrado). A ordenação depende da perspectiva, do ponto de vista e da estratégia do narrador. Mas, o autor também transfere a questão para o processo de recepção, para a experiência e os fluxos de compreensão do leitor (ou ouvinte).

Um dos raros trabalhos que procurou identificar a narrativa jornalística é o de J.F.Sánchez (1992). Ele procura fazer uma aclaração, por contrastes, das características narrativas da ficção, da história e do jornalismo. A distinção entre a narrativa literária e a jornalística se dá, segundo ele, pela diferente intenção de cada um desses discursos (pretensão de verdade). $O$ discurso informativo tem uma finalidade externa ou instrumental, precisa ajustar-se ao mundo real, o conhecimento e o fato conhecido são distintos e o sujeito falante é empírico desde uma situação determinada, se dirige a alguém com a finalidade de comunicar informação. É um ato político e social. O discurso literário, por outro lado, só se compara consigo mesmo, cria o que diz, o sujeito é universal em uma situação eterna, não se dirige a nada, mas a todos indiferenciadamente em todos os tempos. É um discurso absoluto. Já as narrativas histórica e jornalística, embora diferentes, têm para ele inúmeras semelhanças e dessemelhanças dependendo do grau de rigor, do uso de fontes, tentativa de isenção, tratamento das personagens e linguagem.

$28 \mathrm{O}$ fator que distingue a narrativa jornalística das outras duas, segundo Sanchez, é de ordem interna: o nível e grau da composição dos fatos em uma intriga coerente. As exigências da composição da intriga em construir sentidos encadeados (contar histórias) obrigam o autor a introduzir fatos que podem não corresponder à realidade. O jornalismo, com a responsabilidade que tem de contar fatos ainda abertos e falar de pessoas que ainda não terminaram de viver, transita na corda bamba entre a informação narrativa de boa qualidade e a informação vazia de má qualidade (pirâmide invertida) que não integra fatos e pessoas. O autor enumera algumas diferenças e semelhanças, mas não ajuda a identificar o específico da narrativa jornalística ao afirmar que ela transita entre boas e más narrativas na sua vacilação entre restringir-se ao referente ou integrar pela ficção. As definições da singularidade narrativa revistas até aqui transitam entre as qualidades intrínsecas do texto (contar uma história cronológica ou causal coerente, conectar ações contínuas/descontínuas rumo a um desenlace, relatar sucessão de estados de transformação) e as possibilidades e necessidades do receptor em fazer ele mesmo essas conexões no ato de recepção (o texto constrói uma história que remete à imaginação, o relato das ações estimula a imaginação, a conexão depende do leitor/ouvinte). $O$ texto jornalístico transitaria no dilema entre ater-se ao referente empírico 
evitando contar e a necessidade de contar e fazer as conexões, que podem não corresponder ao "real".

Devemos reter as oposições formais entre narrar e descrever, mostrar e contar, texto e história ou texto e fábula, assim como o conceito de narratividade (sucessão de estados de transformação) das discussões acima. Mas, a questão de fundo parece não estar nas qualidades intrínsecas ou estilo dos textos e sim na relação entre texto e imaginação. entre texto e recriação da diegese da história. Para prosseguir nossa conversa. parece mais importante dirigir a discussão para as relações entre narratividade e os processos de recepção. Os enunciados jornalísticos não possuem ficcionalidade, uma atitude de fingimento consensual que se estabelece entre autor e leitor no jogo da fíç̧ão (suspensão voluntária da descrença). Mas. narram sucessões de estados de transformação. ainda que de forma fragmentada e dispersa. Possuem eles a qualidade da narratividade? Como se processam as conexões e ordenações entre os incidentes narrados cada dia pelo jornalismo? Como se constroem as compreensões c significações? A narratividade jornalística conecta as partes, configura histórias? Se há histórias, que significações conformam? Onde estão as fábulas??

\section{Narrativa como mediação entre homem e tempo}

No afã de compreender o conjunto ou o sistema interno e encontrar as constantes científicas, o cpistema estruturalista a teoria literária acabaram concentrando-se nas qualidades internas da narrativa e empurram a mauriz da narratividade para fora da estrutura de temporalidade e da ação comunicativa. Em uma contundente crítica a esse epistema. porém. Paul Ricoeur repôs o paradigma narrativo novamente na conjugação entre intriga e tempo. A análise das idéias de P. Ricoeur na sua pródiga obra Tempo e Narrativa (1994) demanda uma explicação mais longa e nos leva temporariamente para um campo relativamente distante da discussão que vimos fazendo até aqui. Procuraremos não perder o fio da nossa questão original sobre a dimensão narrativa dos enunciados jornalísticos. Mas, pela importância que têm para o paradigma narrativo e o potencial de seus pensamentos para enriquecer as respostas às nossas perguntas, precisamos nojos deter sobre as férteis idéias de Paul Ricoeur.

Ricoeur parte das aporias sobre o tempo nas Confissões de Santo Agostinho e da mimese dramática (imitação ou representação da vida) da Poética de Aristótejes para nos dizer que as narrativas são um meio de reconfigurar a nossa confusa e difusa experiência temporal. Abre para a nossa discussão uma nova trilha, mais densa e pródiga, que perpassa a questão do tempo. A identidade de um texto narrativo, diz o autor, deve ser buscada no caráter temporal da experiência humana porque qualquer narrativa é sempre um mundo temporal. Na verdade, prossegue ele, o tempo torna-se tempo humano na medida em que está articulado de modo narrativo. Dessa 
maneira, a narrativa é significativa na medida em que esboça os traços de nossa experiência temporal.

Para Ricoeur, existe entre a atividade de narrar uma história e o caráter temporal da experiência humana uma correlação que não é puramente acidental, mas que apresenta uma forma de necessidade transcultural. $O$ tempo torna-se tempo humano na medida em que é articulado de um modo narrativo e a narrativa atinge seu pleno significado quando se torna uma condição da existência temporal. O caminho aberto por Ricoeur precisa ser explorado com mais detalhes na medida em que abre trilhas intrigantes para uma posterior compreensão da comunicação jornalística, uma atividade essencialmente marcada pelo tempo (a atualidade, recenticidade, a instantaneidade e a contemporaneidade são valores-notícia determinantes da forma de conhecimento jornalística).

Em sua abordagem da narrativa enquanto processo lingüístico, Ricoeur não segue, como a maioria dos autores da narratologia, o caminho da semiologia nem busca a identidade da narrativa na sua estrutura imanente, como tantos autores. Prefere a via da hermenêutica e da teoria dos atos de fala oriundos da filosofia analítica. Isto significa que ele não parte das leis internas (ou qualidades intrínsecas) que governam a organização do texto (como a narratologia estruturalista), mas da reconstrução do arco obraautores-leitores. Sua tese é a de que a tessitura da intriga resulta de sua posição intermediária de configuração (função mediadora) entre duas operações: o processo de pre-figuração no campo prático (montante) e de reconfiguração da obra no ato da recepção (jusante). Diz ele: "seguimos o destino de um tempo prefigurado em um tempo refigurado pela mediação de um tempo configurado" (Ricoeur, 1994, 87).

Além disso, Ricoeur apóia-se na antropologia cultural (C. Geertz) para argumentar que compreender uma história é compreender, ao mesmo tempo, a linguagem do "fazer" e a tradição cultural (a trama simbólica da cultura) da qual procede a tipologia das intrigas. Situando as intrigas na cultura, o autor introduz a idéia de regras ou normas que dão forma, ordem e direção à vida e alcança assim os pressupostos éticos das narrativas, como defendia Aristóteles. Se a tragédia e a comédia, diz ele, podem representar os "melhores" e os "piores" homens, é porque os autores partilham com o auditório uma hierarquia de valores do bem e do mal. A ação não pode, nem deve ser eticamente neutra, até porque ela oferece aos autores convenções e convicções, mas também ambigüidades e perplexidades (normas conflitivas) a resolver (de modo hipotético). Neste sentido, a poética não cessa de tomar emprestada à ética uma experimentação de valores.

Ricoeur leva-nos a constatar uma estrutura pré-narrativa da experiência temporal do mundo da vida que permanece implícita nas mediações simbólicas da ação, e que ele considera indutora da narrativa (mimese I). Ou seja, a prática cotidiana ordena e articula o passado, o presente 
e o futuro. Valendo-se das aporias de Santo Agostinho para explicar a estrutura temporal primitiva (do mundo da práxis) e do Dasein (o lugar onde o ser que somos é constituído por sua capacidade de colocar a questão do ser e do sentido do ser) de Heidegger, ele observa que não há tempo passado nem tempo futuro, só há um tríplice presente, um presente das coisas passadas, futuras e presentes. um intercâmbio que a ação efetiva faz aparecer entre as dimensões temporais.

Essa relação humana com o tempo se realiza através da intratemporalidade (ser-no-tempo), onde o conceito "vulgar" do tempo cronológico (sucessão de agora-abstratos) é dessubstancializado para dar lugar a um tempo existencial, uma grandeza relacionada às nossas preocupações com a morte, com o reter (passado) e com a espera (futuro). É sob o conceito de intratemporalidade que se edificam, para Ricoeur, as configurações narrativas e as formas existenciais da temporalidade que the correspondem: "imitar ou representar a ação é, primeiro, pré-compreender o que ocorre com o agir humano, com a sua semântica, com a sua simbólica, com a sua temporalidade. É sobre essa pré-compreensão. comum ao poeta e a seu leitor, que se ergue a tessitura da intriga, e com ela. a mimética textual e literária“" (pág. 101).

É nas operações de configurações da tessitura da intriga (que ele chama de mimese Il) que concentra o cerne das teses de P. Ricoeur, entretanto (pág. 101-110). As operações de configuração exercem, segundo ele, uma mediação entre a pré-compreensão (montante) e a pós-compreensão (jusante). A tessitura da intriga faz. primeiro. a mediação entre os incidentes individuais e uma história (transforma os incidentes em uma intriga). Segundo, compõe fatores heterogêneos como agentes, fins, meios, circunstâncias, etc. Aristóteles já igualava a intriga a uma configuração, que Ricoeur chama de concordância-discordância. traço que para ele constitui de modo definitivo a função mediadora da intriga. Terceiro, o tecer da intriga realiza uma síntese do heterogêneo (totalidade orgânica) na medida em que combina duas dimensões temporais, uma cronológica (episódica história de incidentes) e outra configurante que constitui a unidade configuradora de uma sucessão (não cronológica). Seguir uma história é avançar no meio de contingências sob a conduta de uma esfera que encontra sua realização na conclusão. Mas, a conclusão não é o final da intriga, é a síntese entre o tempo narrativo linear e a dimensão configurante que transforma a sucessão de incidentes em uma totalidade significativa (tema).

Finalmente Ricoeur fecha o círculo ao dizer que é no ouvinte ou leitor que se conclui o percurso da mimese. onde se realiza a interseç̧ão entre o mundo do texto e o mundo do receptor (mimese III). Porém. esse círculo não é um círculo vicioso. "Primeiro, a experiência do tempo não se reduz à simples discordância. Segundo, se por um lado a narrativa dá forma ao informe na medida em que a consonância narrativa se impôe à dissonância 
temporal (a ordem é a nossa pátria a despeito de tudo, diz ele), por outro, a tessitura da intriga nunca é o triunfo da ordem. As intrigas coordenam tensão e intenção, terror e piedade, começo (o gêneses) e fim (o apocalipse). Além disso, continua o autor mais adiante, estamos inclinados a ver no tecer das intrigas o encadeamento de episódios de nossa vida ainda não contados, histórias que oferecem pontos de ancoragem à narrativa. Essa pré-história da história é o que a vincula a um todo mais vasto e lhe fornece um "pano de fundo", uma imbricação viva de todas as histórias. Narrar é, assim, um processo secundário que emerge desse pano de fundo: "Narrar, seguir, compreender histórias é só a continuação dessas histórias não ditas"...Contamos histórias porque finalmente as vidas humanas têm necessidade e merecem ser contadas" (pág.116).

Não podemos aqui rever com todos os detalhes o fértil pensamento do autor sobre a relação entre tempo e narrativa. Vamos suspender, por enquanto, este rápido recorrido do pensamento do autor encerrando a conversa sobre a relação entre o texto e o mundo do leitor pois, como diz $P$. Ricoeur, seguir uma história é atualizá-la na leitura. É no ato de ler que o destinatário joga com as coerções narrativas, efetua os desvios e realiza o prazer do texto. É o leitor que conclui a obra, "que quase abandonado pela obra carrega sozinho o peso da tessitura da intriga". Seguindo W. Iser, H. R. Jauss e R. Ingarden, teóricos do ato de leitura e da estética da recepção, conclui ele: "O texto é um conjunto de instruções que o leitor individual ou 32 público executa de modo passivo ou criador. $O$ texto só se torna obra na interação entre o texto e o receptor" (pág. 118), e assim fecha P. Ricoeur o seu ciclo das três mimeses.

Recapitulando, afirma Ricoeur, a narrativa atinge o seu pleno significado quando se torna uma condição da existência temporal. A identidade de um texto narrativo deve ser buscada no caráter temporal da experiência humana porque a narrativa é sempre um mundo temporal, o tempo tornado humano na medida em que este é reconfigurado de modo narrativo. Assim, esse autor repõe com firmeza a questão do tempo e da ação comunicativa no cerne do paradigma narrativo porque não identifica a narratividade como uma qualidade intrínseca do texto e sim da relação obraautor-leitor desde a hermenêutica, a teoria dos atos de fala e a antropologia interpretativa. São esses campos que the fornecem os argumentos para afirmar que as narrativas não cessam de realizar uma experimentação de valores éticos e morais, um fundo antropológico pré-narrativo comum ao autor e ao leitor, e indutor da narratividade. A tessitura da intriga transforma, assim, os incidentes em histórias (sínteses). É no leitor ou ouvinte, diz Ricoeur, que se fecha o percurso da representação (mimese): seguir uma história é atualizá-la na leitura. É o leitor que conclui a obra, que leva adiante criativamente a reconfiguração da intriga e da diegese da história. 
Está aberto, a meu ver, um caminho mais fértil e de muito maior poder explicativo e analítico para o exame dos enunciados jornalísticos como narrativas. A força narrativa dos enunciados jornalísticos estaria menos nas qualidades narrativas intrínsecas do texto das notícias e reportagens ou no confronto entre o estilo descritivo e o narrativo, mas principalmente no entendimento da comunicação jornalística como uma forma contemporânea de domar o tempo, de mediar a relação entre um mundo temporal e ético (ou intratemporal) pré-figurado e um mundo refigurado pelo ato de leitura. Uma trilha que põe a narrativa no campo dos atos de fala e das relações pragmáticas.

Desde esta perspectiva. o jornalismo configura narrativas de experimentação ética e moral, revela-se como via de reconfiguração da cultura contemporânea. Essa reconfiguração se realiza nos atos de leitura das notícias de cada dia quando o leitor. ouvinte ou telespectador criativamente reinterpreta, sob o mesmo fundo cultural do autor, o percurso de representação dos dramas e tragédias do homem moderno. Assim, uma análise da narrativa jornalística não fica dependente da descoberta de pequenas incrustaçoes de formas narrativas no texto predominantemente objetivo e descritivo do jornalismo nem de descobrir até onde o texto descritivo de uma notícia ou reportagem transfigura-se em mini ou pseudo narrativas. Isso pode ser importante, mas não é determinante.

No jornalismo diário há muitos textos híbridos onde se mesclam narração e descrição. Mesmo as notícias que se ocupam de temas "duros" $e$ são expressas na forma objetiva para enxugar as subjetividades estão impregnadas de fragmentos narrativos. Os jornalistas não conseguem e nem pretendem se despojar de toda subjetividade. Por exemplo: quando um jornal anuncia em linguagem objetiva no duro noticiário de economia que o presidente do Banco Central vai manter ou modificar as taxas de juros, a matéria vem recheada de pequenos depoimentos de empresários ou de assalariados que relatam como a medida afeta seus negócios, suas empresas, suas vidas. O "fato duro" é inserido no drama da vida e as fotos que ilustram tais reportagens mostram quase sempre homens e mulheres, seres humanos afetados pela medida. E assim, suavizam a hard news com uma pitada de soft news, narrando no meio da descrição, aproximando o leitor da obra e lhes fornecendo pistas discursivas indutoras da narratividade para que ele. leitor. "realize as experimentaçōes éticas e morais. ${ }^{10}$

Mas, não é na incrustação nem na hibridização do gênero ou do estilo do texto que o paradigma narrativo se revela no jornalismo. A realização da intriga e da diegese narrativa do jornalismo não está nas contradições e derrapagens da linguagem das notícias: está no movimento entre a préconfiguração. a configuração e a refiguração do ciclo pragmático autor-obraleitor, que pode ser capturada, como nos sugere P. Ricoeur, através da interpretação da comunicação jornalística desde una ótica do leitor. Ou seja, 
é desde o ponto de vista reconfigurador da recepção e desde um pano de fundo cultural, ético e moral que podemos reconstituir episódios fragmentados das notícias diárias em narrativas coerentes, que podemos reconstituir intrigas e histórias cuja significação está muito além dos conteúdos proposicionais. É desse ponto de vista, a meu ver, que o jornalismo se configura como narrativa da contemporaneidade. Sua significação é cultural e sua interpretação precisa ser antropológica.

\section{A experiência da recepção das notícias e a reconfiguração narrativa}

As formulações de P. Ricoeur sobre reatualização da história no ato de leitura remetem nossa discussão à estética da recepção estética de Hans Robert Jauss e à antropologia literária de Wolfgang Iser, pensadores da Escola de Constanza, na Alemanha. Com as teorias da recepção desses autores podemos acrescentar elementos para melhor compreender como leitores, ouvintes e telespectadores reconstroem sínteses significativas de fragmentos de significações das dispersas notícias diárias.

Uma discussão há muito em andamento na filosofia e na estética ainda está por ser feita no jornalismo para entender as diferenças entre a experiência estética e a experiência cognitiva de realidade na recepção da notícia (de um lado, a comoção predominantemente estética, de outro, a apropriação predominante de informações). Por causa do caráter fático dos enunciados jornalísticos, pode ser que a recepção da notícia coadune-se mais com a experiência cognitiva de realidade do que com as radicais experiências estéticas e simbólicas. Sem aprofundar-me na discussão creio, entretanto, que a recepção da notícia é um lugar cognitivo em que os homens aprendem algo de si mesmos e de sua realidade, mas é também um lugar de consumação de experiências estéticas, de gozo e de comoção simbólica. Um lugar onde os homens percebem e simultaneamente experimentam o mundo. Sigo aqui o caminho intermediário apontado por H.R.Jauss (2002) para a experiência estética: a recepção da notícia estabelece um saber prático, mas simultaneamente nos transporta à experiências imaginárias.

A recepção das notícias diárias nos remete primordialmente para o mundo fático, mas. não impede a vivência mais ou menos fugaz de um distanciamento imaginário que paradoxalmente esvaece o mundo fático, liberando o sujeito do seu mundo da vida. Como diz Jauss $(2002,41)$, a experiência estética é sempre liberação de e liberação para, como manifesta a doutrina aristotélica da catarse: "A instalação em um destino imaginário requerida pela tragédia libera o espectador dos interesses práticos e dos laços afetivos da vida para ativar os puros efeitos de compaixão e temor que a tragédia desperta". Esses afetos, prossegue ele, são uma condição prévia para levar o expectador, mediante a comoção trágica, à desejável disposição 
de ânimo para compreender o exemplar do proceder humano. Pode haver afirmações mais apropriadas do que essas sobre a experiência de recepção de notícias que relatam cada dia dramas e as tragédias humanas? ${ }^{11}$

Em outro texto sobre o ato de recepção como experiência mediatizada cmpírica, H. R. Jauss é ainda mais enfático sobre os horizontes de expectativas que se abrem no ato de leitura. Nos diz ele que o ato constitutivo do processo total de recepção é a recepção de estruturas, esquemas ou sinais que orientam previamente, em cujo marco de referência o conteúdo do texto é percebido e o significado realizado. Entretanto, esse ato de recepção não deve ser entendido como a união mecanicista de ação recíproca texto-leitor, ou seja. como efeito ou concretização condicionada do destinatário pelo texı. A recepção deve ser concebida como um processo de fusão de horizontes.

A fusão do horizonte de expectativas intraliterárias com o mundo da vida no processo de recepção do texto não se realiza de uma maneira puramente empírica, mas através da formulação de hipóteses, verificação ou refutação. Um processo hermenêutico mediatizado e criativo de compreensão de sentidos: "O leitor só pode converter um texto em fala. isto é, converter o significado atual (do texto) em sentido potencial da obra, na medida em que o introduz no marco de referência dos antecedentes literários da recepção, de sua compreensão prévia do mundo que inclui suas expectativas concretas procedentes do horizonte de seus interesses, desejos, necessidades e experiências, condicionados pelas circunstâncias sociais especificas de cada estrato social e também as circunstâncias biográficas" (Jauss, 1987, 77). Essa fusão de horizontes tanto pode realizar-se espontaneamente no desfrute de expectativas cumpridas quanto reflexivamente através de consideração distanciada, do reconhecimento do estranho. do descobrimento de um modo de proceder, de uma resposta a um estímulo mental. Essas palavras de Jauss sobre a recepção estética parecem-me adequadas para compreender à recepção como ato mediador de construção de sentidos a partir dos dramas e tragédias veiculadas diariamente pelas notícias.

Vejo mais ajustadas ainda à compreensão do ato de recepção das fragmentadas notícias diárias as palavras de Wolfgang Iser sobre a estética da recepção literária. Reproduzo aqui uma síntese do pensamento do autor convidando o meu leitor a pensar, enquanto as lê. sobre o ato de recepção dos dramas e tragédias reportados continuamente pelas notícias diárias. Diz textualmente Iser: "Como nenhuma história pode ser contada na íntegra, o próprio tex to é pontuado por lacunas e hiatos que têm de ser negociados no ato da leitura. Tal negociação estrei.a o espaço entre texto e leitor, atenua a assimetria entre eles, una vez que por meio dessa atividade, o texto é transportado para a consciência do leitor: Se a estrutura básica do texto consiste em segmentos determinados interligados por conexões indeterminadas, entāo o padrão textual se revela um jogo, uma interação 
entre o que está expresso e o que não está. $O$ não expresso impulsiona a atividade de constituição do sentido, porém sob o controle do expresso. Expresso esse que também se desenvolve quando o leitor produz o sentido indicado" (Iser, 1996, 28). Desse modo, conclui ele, o significado do texto resulta de uma retomada ou apropriação da experiência noemática que o texto desencadeia e que o leitor assimila e controla segundo as suas próprias disposições.

É com esse pano de fundo da teoria da recepção e das idéias de $P$. Ricoeur que penso poder-se construir uma teoria das narrativas jornalísticas. As notícias são fragmentos parciais de histórias, de personagens e atores dos dramas e tragédias humanas contadas e recontadas diariamente, pontuadas de lacunas e hiatos de sentido que precisam ser permanentemente negociados pelo receptor no ato de leitura. As notícias condensam difusamente conflitos, tensões, terror e piedade. É o receptor das fragmentadas notícias quem vai conectar as partes, tecer os laços de significação temporal, preencher as lacunas, reconfigurar as indeterminações, articular passado, presente e futuro, montar os atravessados quebra-cabeças das intrigas e significados através de atos criativos de recepção. É na interpretação imaginativa do leitor ou ouvinte que a narrativa jornalística ganha narratividade e consistência, ganha contornos morais e éticos, reconfigura histórias significativas independente da identidade ou qualidades intrínsecas e dos estilos do texto. $\mathrm{O}$ leitor faz isto porque ele precisa e busca encadear temporalmente os 36 fragmentados episódios das notícias com as difusas histórias de sua vida, repondo continuamente $o$ ato de recepção na cultura, no tempo, no mundo da vida.

O jornalismo é uma atividade mimética: representa a vida, as ações dos homens, dos bons e maus homens, relata os dramas, as tragédias, as sagas e as epopéias contemporâneas. As notícias são relatos fragmentados e contraditórios sobre a nossa existência, sobre as nossas dores e os nossos amores, nossos sofrimentos e gratificações, sobre os acasos e contingências que nos afetam. O jornalismo conta continuamente as histórias dos nossos heróis, nossas batalhas e conquistas, nossas derrotas e frustrações. $\mathrm{O}$ mundo do jornalismo é o mundo da tragédia e da comédia humanas. Como atividade mimética, é sobre esse pano de fundo da cultura e do tempo humanos, com todas as suas fortunas e infortúnios, paradoxos e ordenações, que o jornalista trabalha, e no qual ele se encontra com seus leitores ou ouvintes. Nesses termos, podemos falar de uma poética e de uma narrativa jornalística, assim como falamos em uma poética e uma narrativa literária.

As notícias nascem das ambigüidades dos valores e normas de uma cultura: Plagiando J. Redfield (1975) poderíamos dizer que é com os olhos fixados nas normas culturais que o jornalista apresenta histórias problemáticàs e desviantes ao seu auditório. Ao reportar os dramas e tragédias humanas, os jornalistas estão continuamente testando os limites de nossa cultura, de 
suas normas, valores, regras e jurisprudência. As notícias transformam as tragédias humanas em relatos dramáticos para serem confrontados pelo mundo ordinário da vida. Nas notícias, nossa cultura torna-se problemática em si mesma. Em princípio, as notícias desorientam a audiência com o relato dos fatos dramáticos (a desordem), mas o jornalismo é ambivalente. Simultaneamente apresenta a ordem, deixa no ar alternativas hipotéticas (Motta. 2003 ${ }^{\mathrm{a}}$ ). Nem sempre de uma forma didática. mas frequentemente de uma forma pedagógica. A atividade mimética do jornalismo, assim como da arte, ensina.

Essa afirmação deve ser tomada com parcimônia, entretanto. Assim como a arte, o jornalismo constrói-se sobre as ambigüidades. os dilemas e contradições do mundo da vida. Mas, como o teatro, não apresenta soluções nem promessas de resolver os dilemas. Deixa isto para a religião, a política, as ideologias. O plágio das palavras de J. Redfield sobre a arte dramática pode ser útil para compreender igualmente a experiência da recepção no jornalismo: ela atinge seu clímax e apogeu intelectual quando nos revela o caráter universal e pervasivo das tragédias que diariamente conta. É nesse aspecto que o caráter mimético do jornalismo se revela com mais força: ela leva adiante junto aos receptores, diariamente, sucessiva e permanentemente uma experimentação de valores. O jornalismo toma empréstimos da ética para selecionar e apresentar as notícias, mesmo quando prega uma total suspensão de valores e juízo moral. Ou ainda, como revela P. Ricoeur a respeito da poética, o próprio projeto de neutralidade pressupõe a qualidade originalmente ética da ação.

Estou sugerindo que a recriação de sentidos no processo de recepção deve ser observada através de uma abordagem antropológica da notícia (a notícia como produto de mediação cultural). Essa abordagem propõe a observação das fragmentadas notícias de cada dia como sequiencias interruptas de episódios singulares que configuram encadeamentos narrativos unitários como intrigas com princípio, meio e fim, como narrativas. Encadeados, os fragmentados incidentes diários reportados recompõem seqüências de significações abertas, mas unitárias, totalidades cuja determinação sintática se manifesta de forma latente no texto, mas que só pode ser coerentemente reconfigurada no ato de interpretação. É na imaginação dos leitores que se constrói a fabulação (moral e ética) dos fragmentados cventos diários. Na observação narrativa e pragmática da comunicação jornalística podese, então, compreender os processos cognitivos e simbólicos dessa fabulação do real (Motta, 2002 c 2003). ${ }^{2}$ Essa questão nos remete à discussão, no âmbito da historiografia, sobre a história narrativa e particularmente sobre a história do presente, sobre o acontecimento 
histórico e o acontecimento jornalístico, e nos fornecem elementos necessários para a conclusão de nossa reflexão sobre o caráter narrativo do jornalismo.

\section{Conclusão: acontecimento jornalístico e refiguração narrativa da história do presente}

O historiador Robert Darnton (2004) despertou recentemente a nossa atenção para um fenômeno novo que ocorre nas ciências da história: o aumento do número de estudos sérios sobre fatos dramáticos relativamente curtos, narrados como contos, que ele chamou de "análise de incidentes". Por um lado, diz ele, esses estudos respondem à fome de conhecimento histórico. Por outro, levantam uma velha questão: "o passado, quando visto de perto, parece mais inescrutável que nunca". Segundo o autor, há uma dupla preocupação nas "análises de incidentes": uma reconstrução acadêmica, mas também uma abordagem narrativa dos eventos.

Essas "análises de incidentes" levantam perguntas importantes para Darnton: "O que realmente aconteceu? O que separa o fato da ficção?" Ou ainda "onde está a verdade entre interpretações correntes"? As indagações de Darnton trazem duas questões com as quais queremos concluir nossa tentativa de responder às perguntas formuladas no início deste artigo. Primeiro, a "análise de incidentes" como forma de buscar a compreensão histórica de acontecimentos de significação mais ou menos unitária. Segundo, 38 como os acontecimentos jornalísticos se relacionam à configuração da história do presente ou história imediata, como preferem outros historiadores. ${ }^{13}$ Nos próximos parágrafos, vamos discutir a primeira questão: a compreensão dos acontecimentos significativos como narrativas compreensíveis sobre a realidade. Ao final, discutiremos muito brevemente a singularidade da narrativa jornalística como história do presente. Deixamos para outro momento aprofundar esse segundo ponto.

1. Escrever a história é contar uma história e, portanto, utilizar muitos dos mesmos dispositivos que entram na fiç̧ão, diz R. Darnton. Há riscos de se fazer má história ou má ficção, e até as duas coisas, adverte ele. Mas, esse risco existe em qualquer outra atividade. O que distingue uma boa análise de incidentes é sua matéria-prima, seus métodos e sua ambição: "ela lida com a concatenação de eventos, mais que os próprios eventos apenas". Ao se concentrar em eventos, tenta entender a maneira como as pessoas interpretaram sua experiência, mais que o modo como elas se encaixam em estruturas. Hoje, conclui o historiador, como os eventos da mídia dominam os noticiários, uma história sobre como os eventos se tornaram incrustados na mídia deveria despertar um interesse maior.

O tema trazido por Darnton não é novo, refere-se a uma discussão já longa da historiografia sobre a análise dos acontecimentos (que Darnton chama de análise de incidentes). Durante muito tempo o acontecimento 
pareceu inseparável dos relatos da historia (histoire événementielle) e consolidou-se como referência objetiva da historiografia positivista até sofrer uma crítica frontal da "nova história" que se refere ao acontecimento como simples "agitação de superfície". Mas, a análise do acontecimento não desaparece do horizonte dos historiadores e recupera o seu status a partir de um artigo de P. Nora (1979), que refuta o acontecimento "natural", mas retoma o acontecimento discursivo na inflação de acontecimentos da contemporaneidade midiática. "Multiplicado, desmesuradamente inchado pelos meios de comunicação que o produzem, o acontecimento nos oferece a leitura do imaginário de uma sociedade, para a qual representa ao mesmo tempo o papel de memória e de mito", diz J. Revel (s/data).

A compreensão narrativa dos acontecimentos jornalísticos caminha paralela à compreensão dos incidentes reportados isoladamente cada dia pela mídia como eventos pontuais que vão adquirir sentido narrativo no ato de recepção. Somos induzidos a pensar que os incidentes narrados precisam adquirir na mente do leitor ou ouvinte um encaixe de sequiências encadeadas e compreensíveis. A determinação do receptor é construir significados integrais. Como diz M. Schudson (1999), notícias são news e são story (o inglês tem as duas palavras), são fatos novos, mas são também histórias. Porque são histórias, os leitores estão sempre procurando o começo, o desenvolvimento e o desfecho dos acontecimentos ${ }^{14}$. Assim, as fragmentadas notícias do dia-a-dia conformam naturalmente integralidades difusas, acontecimentos unitários significativos. As notícias de cada dia podem prolongar a conformação do enredo e retardar o desenlace do acontecimento. como ocorre nos contos e romances. Mas, a busca do leitor é sempre por sentidos unitários, por conexões compreensivas.

As notícias diárias podem então ser compreendidas como microepisódios de sentido inacabado relacionados a algo gradualmente refigurado na imaginação dos receptores com o auxílio da memória. Gradualmente o leitor vai preenchendo imaginativamente as lacunas, construindo conexões, recompondo a narrativa e fazendo a fusão de horizontes, conforme vimos acima. O que the permite "seguir virtualmente as pegadas da história" são os fatores redundantes (a continuidade temática, o cenário das ocorrências, as personagens, etc.). ${ }^{15}$ Os fragmentos trazidos pelo leitor são a intertextualidade, a acoplagem estrutural de ficções entrelaçadas. Como afirma Iser (1995), cada texto é uma reescrita de outros textos, que são incorporados e armazenados no texto em questão. A intertextualidade forma o padrão básico da memória cultural.

Não basta estabelecer relaç̧̇es cronológicas de transformação entre as notícias de ontem, as de hoje e as de amanhã, entretanto. Não é o estabelecimento de uma ordem temporal de incidentes ou ações no desenrolar de uma história, como pretendia V. Propp (1984) no seu trabalho pioneiro, que garantem a narratividade das notícias dispersas. Nem tampouco o 
estabelecimento lógico-causal de uma sintaxe funcional, como defendia o estruturalismo de A. J. Greimas (1971) e T. Todorov $(1971,1970)$ que garante um caráter narrativo aos enunciados jornalísticos. Para um analista qualquer, a identificação de uma história semanticamente coesa é um passo inicial indispensável, sem o qual não se pode avançar. Mas, a coesão da história só será plena na virtualidade da experiência cognitiva e simbólica do receptor, na imaginação narrativa do leitor ou ouvinte.

Se defendemos a refiguração narrativa do texto nos processos de recepção, como sủgere $P$. Ricoeur e mais particularmente a teoria da recepção estética, é na fusão de horizontes que ocorre no ato de leitura onde devemos buscar a reconstrução de uma coerência narrativa virtual estimulada pelo texto jornalístico. No ato de leitura, o caráter fático dos enunciados jornalísticos remete o receptor da notícia para uma experiência cognitiva de realidade, mas a necessidade de reconstruir significados narrativos unitários o impele rumo a experiências simbólicas. $O$ ato de recepção das notícias é um momento cognitivo em que os homens aprendem algo de si mesmos e de sua realidade, mas é também um momento de branda ou intensa comoção simbólica, dependendo de cadả notícia e situação. Um lugar onde os homens percebem e simultaneamente experimentam o mundo, como já dissemos.

Para entender esse processo cognitivo e simbólico de fusão de horizontes recorremos às idéias do filósofo J. Dewey $(1998,22 / 3)$ sobre a construção de significados pela mente reflexiva, que ele considera 40 semelhante a uma construção narrativa. No pensamento automático e incontrolado, diz ele, há um fluxo contínuo não regulado de impressões e imagens. Mas, no pensamento reflexivò, há uma ordenação seqüencial de idéias em que cada uma determina a seguinte, que por sua vez remete às que precederam: cada fase é um passo de algo rumo a algo. A exigência de diminuir ou extinguir a ambigüidade é o fator orientador e estabilizador (a lógica é nossa casa, dizia acima P. Ricoeur). A corrente se transforma em cadeia de pensamentos e imagens ligados entre si num movimento dirigido a um fim comum, a uma conclusão reflexiva. Há em cada experiência cognitiva uma sucessão mais ou menos coerente de incidentes e episódios unidos por ruptura de continuidade, narrações imaginadas e lógicas. Ou seja, uma - experiência narrativa.

Mas, o que importa, observa Dewey, não é a sequiência, é a conseqüência. Os significados inconscientemente construídos dessa forma têm por trás deles um "fundo de verdade", uma crença em algo que transcende e ao mesmo tempo certifica seu valor. A crença realiza uma afirmação a cerca de uma questão de fato, de um princípio, de uma lei. $O$ mais importante são as sucessões mais ou menos coerentes de incidentes e de episódios imaginativos unidos sem ruptura de continuidade entre si, que podem estar a meio caminho entre as fugazes imprecisões caleidoscópicas da fantasia e as considerações deliberadamente utilizadas 
para estabelecer uma conclusão. ${ }^{16}$ Para ele, o pensamento reflexivo (narrativo) tem um propósito que transcende a mera diversão, que deve conduzir a algum lugar, que solicita uma conclusão. Há uma meta que se pretende alcançar e essa meta impóe o controle sobre a sequiência de idéias, impõe uma combinação coerente $\mathrm{em}$ direção a uma conclusão unificada (Dewey, 1998, 56/7).

Esse pensamento se assemelha às idéias do psicólogo cultural $\mathrm{K}$. Gergen (1996,232). Diz ele que as pessoas vivem os acontecimentos da vida cotidiana de modo narrativo porque estão imersos em narrações que vão carregando de sentido os relatos: "adquirem a realidade de um princípio. de um ponto grave, de um clímax e de um final, e assim sucessivamente." As pessoas vivem os acontecimentos desse modo e os classificam precisamente assim. Por isto, não dizemos que a vida copia a arte, mas que a arte se converte no veículo através do qual a realidade da vida se torna manifesta: "em um sentido significativo, pois, vivemos mediante narrações, tanto ao relatar como ao realizar o eu".

Não só contamos nossas vidas como relatos, mas também nos relacionamos com os outros de forma narrativa, observa Gergen. A consciência humana, continua ele, é um fluxo contínuo de sequências dirigidas a metas: compreender uma ação é situá-la no contexto dos acontecimentos precedentes e conseqüentes. Muito distante dos enfoques imanentes e internos às estruturas das narrativas, as narrações segundo esse ponto de vista são instrumentos lingüísticos incrustados nas sequiências convencionais de ação e empregados nas relações de tal modo que sustêm. intensificam ou impedem formas de ação: funcionam como histórias morais, recursos de origem sociocultural (intersubjetivos). As narrações estão cultural e historicamente situadas, são subprodutos dos intentos de se relacionar através dos discursos. Um relato estabelece um ponto final a alcançar, isto é, estabelece um forte componente cultural que se deriva da ontologia da cultura (p. 236), seleciona acontecimentos relevantes a partir deste ponto final, ordena os incidentes segundo o cronotropos culturalmente definido (p. 238).

É o mesmo ponto de vista de outro psicólogo cultural, Jerome Bruner (1998), para quem a psicologia popular (o senso comum) é de natureza narrativa. não de natureza lógica ou categorial: a psicologia popular trata de agentes humanos que fazem coisas baseando-se nas suas crenças e descjos. e se esforçam para alcançar metas. As narrativas são inerentemente sequienciais. diz ele. Mas, essas sequências não possuem um significado próprio, este só se realiza na configuração global da totalidade da sequência: "sua trama, sua fábula" (p. 56). Podem ser reais ou imaginárias sem perder o seu poder simbólico de configuração global, independente de sua verdade ou falsidade. As narrativas, diz Bruner, fundam suas raizes em nossa ancestral herança de contar histórias (p. 57). 
Para Bruner, há uma predisposição cultural em organizar a experiência de forma narrativa mediante estruturas de tramas (mimese): captar a vida em ação, adaptando e melhorando o que sucedia. Estar na história, diz ele parafraseando a P. Ricoeur, tem um parentesco com contar uma história. Há uma mútua correspondência entre a forma de vida e o discurso narrativo: a mimese é uma metáfora da realidade, refere-se à realidade não para copiá-la, mas para outorgar a ela uma nova leitura. É por isso que a narrativa pode seguir adiante independente da exigência de referencialidade, sem a obrigação de ter um correspondente no mundo. As narrativas, diz o autor, mediam entre o mundo canônico da cultura e o mundo idiossincrático das crenças, desejos e esperanças, reiteram as normas sem serem didáticas (p. $63)$.

Reunindo as contribuições da psicologia cultural às da história, vamos encontrar em um artigo (que se tornou um clássico) do historiador Hayden White (1980) os argumentos para ancorar com segurança nossa tese sobre a construção da narratividade no ato de recepção das notícias. As narrativas, diz ele, são uma particularidade humana mais que uma especificidade cultural, são um meta código humano universal. White insiste que as narrativas, sejam elas factuais ou fictícias, têm um motivo de ordem legal que provê o impulso para narrar e configurar as histórias. Esse impulso, diz ele a título de hipótese seguindo a Hegel, é o conflito entre o desejo e a legalidade, a legitimidade, ou a autoridade genericamente concebida. Narrar

42 histórias seria impensável sem a pressuposição de um sistema de leis em relação à qual uma consciência histórica pode ser possível. São as relações humanas governadas por leis, legalidades e legitimidades que provêm as tensões e os conflitos que tornam'possível representar a realidade como história, seja ela real ou imaginária.

A conclusão de White é radical: se cada história é um tipo de alegoria moral, seu objetivo latente ou manifesto é moralizar os eventos e a realidade de que trata. Ele sugere, então, que a narratividade está intimamente vinculada ao impulso de moralizar, de estabilizar a realidade. As idéias de White nos levam a pensar sobre a existência do jornalismo como crônica da realidade cotidiana. Contra qual realidade ética (pano de fundo moral) escrevem diariamente os jornalistas? "Good news is no news", diz o ditado jornalístico. Se não há conflito, não há notícias, as notícias estão sempre relacionadas a inversões e transgressões. $\mathrm{O}$ acontecimento jornalístico, disse há tempos A. D. Rodrigues (1993), é aquilo que rompe na superfície lisa da história, é o negativo da racionalidade. Neste sentido, conclui ele, o jornalismo inscreve-se inequivocamente no processo de regulação social, é uma prevenção racionalizante: o discurso dos mídia surge para reorganizar a experiência do aleatório e the conferir racionalidade. As palavras de White (pág. 18/19) para a historiografia são muito semelhantes: se nada há de 
problemático, se não há contestação, nada há para representar nem história para ser contada. É porque, e só porque há contestação, que algo surge para ser narrado.

Em artigo anterior (Motta, 2003a), observei que a notícia enquanto ritual simbólico desempenha difusamente um papel de mediação entre os homens e uma cosmovisão, ainda que confusa e muito sub-repticiamente percebida. Argumentei que, como todo ritual que reporta continuamente as indeterminações, a notícia pode ser entendida como uma práxis de dominação da contingência. Utilizei as palavras de L. Duch $(2002,190)$ sobre os atos ritualísticos em geral para reforçar meu ponto de vista: "todo ritual pretende ser uma terapia benéfica destinada a remediar, a nível individual e coletivo, os estragos da negatividade, uma estratégia para voltar a integrar as forças que, na existência humana, atuam de maneira caotizante...uma reintegração do todo que havia sido "centrifugado" da vida humana como conseqüência da ação do mal e da morte, uma consolidação do nós coletivo e social... a fim de evitar a desagregação e a desestruturação provocada pelos interesses de todo tipo, pela inimizade, pela incompreensão e pelo medo."

Em última instância, conclui então, é esse o papel cognitivo da noticia: uma estratégia simbólica destinada, a nível individual e coletivo, a fazer frente a os estragos da negatividade e voltar a reintegrar o todo ameaçado, consolidando o conjunto social e evitando a sua desestruturação pela angústia, ansiedade e medo diante da contingência. É assim, portanto, no âmbito da cultura, não das imanências internas, que é possível reconhecer as determinações canônicas que configuram o caráter narrativo dos enunciados jornalísticos. Cabe ao analista identificar os impulsos morais e éticos no âmbito da cultura que configuram significativamente os dramas e tramas das narrativas jornalísticas, independente de seu maior ou menor grau de objetividade ou de narratividade interno.

2. Há algo singular no caráter da narrativa jornalística, além de sua configuração moral. Diferentemente da história, a narrativa jornalística, ainda que utilize predominantemente o pretérito perfeito ou imperfeito em seu discurso, refere-se ao presente, ao momento contemporâneo. Um momento fugaz, fugidio, sempre provisório. Essa coetaneidade confere uma singularidade à narrativa jornalística em relação às narrativas da história ou da literatura. O jornalista narra continuamente a história do presente imediato, uma história fugidia, inacabada, 
aberta, mas, uma história. Negar às narrativas jornalísticas o caráter de história é fazer coro com a atitude positivista que negou à atualidade a dignidade de história, como nos diz o historiador P. Nora. O presente intensificou-se, diz ele, está super aquecido, adquiriu uma dimensão histórica. Antes de qualquer elaboração crítica, o presente é vivido diretamente como história e se impõe ao historiador desde o exterior, história falada, escrita, televisionada: "se em algum lugar pulsa o coração da história contemporânea, não é no silêncio dos arquivos, mas no burburinho da sala de redação ou de uma conferência de imprensa" (Nora, s/data, pág. 535). O jornalista, afirma ele, é o historiador natural da atualidade. A história do presente não é um simples apêndice linear da história do passado, mas uma história distinta, cuja particularidade é justamente sua exclusão do campo da história. ${ }^{17}$

Não podemos entrar aqui na instigante discussão sobre o conceito de história do presente. Queremos regressar à análise dos acontecimentos, que R. Darnton chamou de análise de incidentes, para concluir nossa reflexão do jornalismo como narrativa do presente. Gostaria de mudar ligeiramente as perguntas de Darnton sobre o sentido dos acontecimentos: Qual a significação dos acontecimentos que se precipitam sobre nós desde os mass media? Como compreendê-los? Onde encontrar os fios que conectam as histórias e tornam os acontecimentos compreensíveis? P. Nora (1979) observa que um novo tipo de acontecimento vinculado ao jornalismo vislumbra hoje uma história distinta. $\mathrm{O}$ sistema de atualidade tem o seu modo de produção, os mass media, e seu produto estandardizado, o acontecimento. Mas, um acontecimento diferente das efemérides do passado, que busca continuamente uma consciência de si mesmo. $\mathrm{O}$ acontecimento jornalístico, conclui ele, constitui-se no centro do nosso presente histórico.

A partir da serialidade da cobertura de incidentes fragmentados noticiados diariamente pela mídia o analista pode reconstruir narrativamente o enredo de um acontecimento midiático, como uma breve história. Mas, a sua análise não acaba aí, começa aí. A qualidade narrativa não está no estilo nem na revelação do encadeamento da história, mas na mediação da relação do homem com o tempo nos atos de fala. Reunindo e encadeando as notícias diárias como histórias unitárias potenciais, como parece fazer o receptor, é possível recuperar sua configuração temporal com um mínimo de consistência e a partir daí, observar o fundo moral que projetou as notícias diárias. Seguir uma história, diz Ricoeur, é atualizá-la no ato de leitura. Partindo dos atos de leitura, é possível recuperar as atualizações narrativas processadas a partir do jornalismo. É no ato de ler que o destinatário joga com a coesão narrativa, conclui a obra, carrega sozinho a tarefa de tecer a intriga, 
como diz Ricoeur. Ficção não é um gênero do discurso, é uma forma de expressão humana. É uma relação intersubjetiva que os indivíduos estabelecem com a realidade. Como se leitores fossem, os analistas podem compreender a fugaz natureza narrativa dos enunciados jornalísticos reconstituindo seus episódios, suas sequiencias, suas intrigas. Assim, recuperar suas fábulas e observar as experimentações éticas e morais continuamente em curso na cultura, independente da referencialidade, do estilo ou grau de objetividade dos enunciados.

\section{Notas}

1.Outras formas de jornalismo, como a reportagem. a crônica, o novo jornalismo, o romance-reportagem têm uma identidade mais íntima com a literatura e fazem maiores concessões poéticas. Buscam outro tipo de relação pragmática com o leitor, diferente do jornalismo factual. Neste caso, a identificação da narrativa na estrutura do texto é mais fácil e imediata. Não trataremos destas expressões narrativas híbridas de jornalismo neste artigo. Nos restringiremos às fragmentadas hard news, aquelas notícias de linguagem direta e objetiva escritas na fórmula do lide clássico, que compõe o grosso do jornalismo diário.

2.As ciências da linguagem percorrem uma extensão que vai da teoria literária (nova crítica, formalismo russo, teorias da recepção, teorias semiológicas estruturalistas, teorias marxistas) passando pelas tradições hermenêutica, analítica e simbólica, pela lingüística, a semântica, a pragmática, a retórica moderna, a sociolinguiística, o pós-estruturalismo, pós-modernismo. teorias do ato de fala, o construtivismo e outras vertentes Não é fácil encontrar um caminho iluminador sobre o paradigma narrativo nessa densa floresta. 3. Mais adiante M. Bal (pág. 57) indica que a história - ponto médio dos três estratos que ele distingue no texto narrativo - não se elabora a partir de um material diferente da fábula, mas se contempla desde certo ângulo específico. Considerando-se a fábula primordialmente como produto da imaginação, caberia entender a história como resultado da ordenação.

4.Estou conscientemente utilizando o conceito de distância de uma forma diferente e até antagônica daquela frequientemente utilizada pela teoria literária. 5.Reis e Lopes observam que se fosse possível demarcar o campo dos textos literários e dos textos narrativos de uma determinada época, dir-se-ia que entre eles se verifica uma sobreposição parcial mais ou menos dilatada. Ver a exaustiva discussão que Reis \& Lopes (1988, pág. 69-79) fazem do conceito de narratividade. 
6. Ricoeur não nega a circularidade, na medida em que o ponto de chegada parece conduzir ao ponto de partida, ou pior, o ponto de chegada parece antecipado no ponto de partida (pág. 111). Mas, qualquer que possa ser a força coercitiva dessa circularidade, pode-se encontrar nela um reforço para o seu argumento segundo o qual a circularidade manifesta de qualquer análise narrativa não é uma tautologia morta. "É preciso, antes, ver aí um círculo saudável no qual os argumentos apresentados nas duas vertentes do problema socorremse mutuamente" (pág. 117).

7. Diz W. Iser (O que é antropologia literária?, 1996, pág. 175): “a intertextualidade, ou seja, a memória do texto, é o caminho para a satisfação desse tipo de anseio, pois permite que os receptores se transponham para dentro das operações das intrigas interligadas que organizam as relações deslizantes dessa rede, fazendo-os passar pela experiência de uma presença que jamais havia sido real ou de fato presente para eles."

8. Não é possível discutir aqui detalhadamente as idéias de Jauss. Transcrevo suas palavras sobre a catarse como propriedade essencial da experiência estética porque creio que elas se aplicam bem à experiência de recepção das notícias. Diz ele que a experiência comunicativa precede as coações institucionais e libera o espectador frente o mundo dos objetos através da imaginação. Nas suas próprias palavras: "Na medida em que o espectador de uma tragédia nega os interesses reais do seu mundo e adquire a instalação estética para a ação da tragédia, se põem em jogo a compaixão e o temor, as condições para a identificação do espectador com o herói, segundo Aristóteles. A catarse como antítese do mundo prático não contradiz em absoluto a identificação estética, mas a pressupõe, principalmente na medida em que é um marco de descolamento comunicativo da consciência imaginativa. A identificação emocional do espectador com o herói como espaço comunicativo pode tramitar modos de comportamento, configurálos novamente ou quebrar normas costumeiras em benefício de novas orientações para a ação. Mas, o espectador também pode encontrar um prazer puramente individual na liberação solitária do sentimento ou permanecer no mero prazer do espetáculo. O espectador liberado pelo prazer dos objetos trágicos pode, mais além da mera identificação, fazer cargo do exemplar da ação e também captar o alheamento dessa identificação, constatá-la e neutralizá-la eticamente depois de permanecer num assombro ingênuo diante dos fatos do herói" (Jauss, 2002,78).

9. É significativo observar que tanto Paul Ricoeur na sua discussão sobre tempo e narrativa quanto Wolfgang Iser na sua antropologia literária partem da antropologia interpretativa de Clifford Geertz. Diz 
Geertz $(1989,207)$ sobre a cultura: “A cultura não são cultos e costumes. mas estruturas de significado através das quais os homens dão forma à sua experiência".

10. Segundo Darnton, há uma dupla preocupação nessas análises. Por um lado, uma reconstrução acadêmica de um fato: de outro, com a história de sua nova narrativa, que distingue esses historiadores da Escola dos Anais. Concentram-se em pequenas unidades onde é possível estudar fenômenos que não podem ser vistos em abstrações mais elevadas. Lidam com a vida cotidiana e com a maneira como as pessoas interpretaram suas experiências (não tivemos acesso ao original inglês e a tradução feita pelo jornal Folha de S. Paulo do texto de R. Darnton é péssima e dificultando sua compreensão).

11. Diz M. Schudson (1999) que as notícias são escritas diariamente como unidades relativamente autônomas, mas elas têm pernas, elas caminham. elas são significados em construção (follow up stories). Na análise que estamos propondo é imprescindível recompor retroativamente a totalidade do acontecimento jornalístico como um bloco semanticamente coeso, tarefa que o leitor realiza inconsciente, mas permanentemente e $o$ analista pode reconstituir, a partir do texto. De forma mais ou menos arbitrária, o analista poderá identificar o princípio, o desenvolvimento e o final do acontecimento que está observando. O início e o final de alguns acontecimentos serão mais fáceis de ser determinados, em outros casos poderá haver um corte mais arbitrário. Em seu auxílio, $o$ analista poderá recorrer às concep̧̃ões de sequências narrativas da teoria literária.

12. Para $T$. Todorov uma sequêencia narrativa completa é formada por no mínimo cinco proposições: situação inicial estável que uma força vem perturbar. Daí resulta um estado de desequilíbrio; pela ação de uma força dirigida em sentido inverso, o equilíbrio é restabelecido; o segundo estado de equilíbrio é semelhante ao primeiro, mas nunca idêntico. P. Larivaille também define como sequêencia-tipo uma sequiência quinária articulada do seguinte modo: 1) situação inicial; 2) perturbação; 3) transformação; 4) resolução; 5) situação final. Observe que as sequiências descrevem sempre um agrupamento semântico coeso que thes confere unidade. Ver Reis e Lopes $(1988,184 / 6)$. No jornalismo. a recomposição da sequiência pode tornar-se problemática porque nem sempre há um início ou um final da história clar:mente configurado, como num romance. Numa sequência de notíci ※, a continuidade deverá ser buscada na reiteração temática, na recorrência de ceñários geográficos, espaços sociais. Ou na recorrência de personagens que tecem o fio da história. Na análise que defendemos, esse é o passo inicial, mas a coerência narrativa deve ser invocada na cooperação interpretativa do leitor, na fusão de horizontes entre o mundo do texto das notícias e o mundo da cultura do receptor. 
13. John Dewey observa que o pensamento reflexivo (formador de significados) está sempre direcionado ao passado e ao futuro (sequenciação). Depende das experiências passadas, não surgem do nada, compara com as 'experiências anteriores, revisa fatos e idéias previas ( $p$. 110). Ao mesmo tempo, projeta visões de futuro, prognostica, conjectura, antecipa, hipotetiza, considera, refuta. Há um momento em que o significado é só uma idéia ou imagem, está só sugerido (p. 121), só se transformará em um significado compreendido quando entendido em contexto (relações): "apreender o significado de um objeto é contemplá-lo em suas relações com outras coisas" (p. 125)".

14. P. Nora (1979) registra a morte do acontecimento natural na história contemporânea, mas identifica o retorno de outro tipo de acontecimento: multiplicado desmesuradamente pelos meios de comunicação que o produzem, o acontecimento contemporâneo nos permite ler o imaginário de uma sociedade da qual representa o papel de memória e, ao mesmo tempo, de um mito. Analisar o acontecimento contemporâneo, sua estrutura, seus mecanismos, o que ele contém de significação social, diz ele, não é interrogar sobre a espuma do tempo histórico, mas aproximar-se do funcionamento de uma sociedade através das representações parciais e deformadas que ela produz.

\section{Referências bibliográficas}

Alvarez, Mirian (2000): Tipos de escrito I: narración y descripción, Arco Libros, Madrid.

Bal, Mieke (2001): Teoria de la narrativa, Cátedra, Madrid

Bruner, Jerome (1998): Actos de significado, Alianza, Madrid

Darnton, Robert (2004): Um assassino sentimental, Cadernos Mais, FSP, 23/ 05/2004.

Duch, Lluís (2002): Antropologia de la vida cotidiana, Trotta, Madrid.

Geertz, Clifford (1989): A interpretação das culturas, LTC, Rio de Janeiro.

Gergen, Kenneth J. (1996): Realidades y relaciones, Paidós, Barcelona.

Greimas, A. J. (1971): Elementos para uma teoria da interpretação da narrativa mítica, in R. Barthes, Análise estrutural da narrativa, Vozes, Petrópolis

Groupe D'antrevernes (1979): Analyse semitique des textes, Presses Univeristaires de Lyon.

Iser, Wolfgang (1999): Teorias da recepção: reação a uma circunstância histórica, in J.C.C. Rocha, org., Teoria da Ficção, UERJ, Rio de Janeiro.

Jauss, Hans Robert (2002): Pequena apologia de la experiência estética, Paidós, Barcelona.

Jauss, H. Robert (1987): El lector como instancia de uma nueva historia de la literatura, in J. A. Mayoral, Estética de la recepción, Arco Libros, Madrid. 
Motta, Luiz Gonzaga (2002): Para uma antropologia da notícia, Revista Brasileira de Ciências da Comunicação, Vol. XXV, No. 2, julho/dezembro.

Motta, Luiz Gonzaga (2003): O jogo entre intencionalidades e reconhecimentos: pragmática jornalística e construção de sentidos. Comunicação e Espaço Público, Ano VI, Nos. 1 e 2.

Motta, Luiz Gonzaga: $\left(2003^{\mathrm{a}}\right)$ : Sobre o trabalho simbólico da notícia, GT Comunicação e Cultura, CDrom Compos 2003.

Nora, Pierre (s/data): Presente, in J.Le Goff, R. Chartier e J. Revel, La nueva história, Mensajero, Bilbao.

Nora, Pierre (1974): El retorno del acontecimiento, Hacer la história, Laia, Barcelona.

Prince, Gerald (1987): Dictionary of narratology, University of Nebraska Press Redfield, James (1975), Nature and Culture on the Illiad. The tragedy of Hector, The University of Chicago Press, Chicago.

Reis, C. e A. C. M. Lopes (1988): Dicionário de teoria da narrativa, Ática. S. Paulo.

Revel, Jacques (s/data): Acontecimento, in J. Le Goff. La nueva história. Mensajero, Bilbao.

Ricoeur, Paul (1994): Tempo e narrativa. Tomo I. Papirus, S. Paulo.

Rodrigues, Adriano D. (1993): O acontecimento, in N. Traquina, JornalismoQuestões, teorias, "estórias", Vega, Lisboa

Sanchez, J.F. (1992): El periodista como contador de histórias, Estudos de periodística, Universidad Complutense, Madrid.

Schudson, Michael (1999): News as literature and narrative, The sociology of news, New York.

Todorov, Tzvetan (1970): As estruturas narrativas, Perspectiva, S. Paulo.

Todorov, Tzvetan (1971): As categorias da análise literária, in R. Barthes (1971), op. cit

White, Hayden (1980): The value of narrative in the representation of reality, in W.J.T. Mitchell, On narrative, University of Chicago Press, Chicago. 
